work, which combines a high degree of scholarship and a wide practical expertise.

The monograph is well indexed and well designed as a communication arts book should be. A glossary of terms would be useful, as would be an appendix of abbreviations found throughout the book.

For the American reader, the National Film Library, formed in 1935, now the National Film Archive, and the references to BBC programming will reinforce the awareness that British techniques of information storage and retrieval are indeed highly advanced, given impetus and support by the well-supported public services aspect of British programming.

Although the work is highly specialized in its major application, it contains much practical information and is recommended as a source book of information on film and information retrieval techniques in a significant format.-Gloria Terwilliger, Director of Learning Resources, Northern Virginia Community College, Alexandria.

\section{OTHER BOOKS OF INTEREST TO ACADEMIC LIBRARIANS}

Atkinson, Frank. Librarianship. Hamden, Conn.: Linnet Books, Shoestring Press, 1974. 112p. (ISBN 0-208-01351-2).

R. R. Bowker \& Co. El-Hi Textbooks in Print 1974. New York: Bowker, 1974. 466p. \$19.95. (70-105104). (ISBN 08352-0697-1).

Carey, R. J. P. Library Guiding. Hamden, Conn.: Linnet Books, Shoestring Press, 1974. 186p. \$10.00. (73-18477). (ISBN 0-208-01350-4).

Downs, Robert B. British Library Re- sources. Chicago: American Library Assn., 1974. 332p. \$25.00. (73-1598). (ISBN 0-8389-0150-6).

Gale Research Co. Book Review Index: 1972 Cumulation. Detroit: Gale Research, 1973. 530p. \$45.00. (ISBN 08103-0557-7).

Greene, Jon S., ed. Standard Education Almanac 1973/74. Orange, N.J.: Academic Media, 1973. 506p. \$25.00. (68-3442). (ISBN 0-87876-039-3).

London, Keith. Documentation Standards. New York: Mason \& Lipscomb, 1974. 253p. \$12.50. (73-12155). (ISBN 088405-052-1).

Marc 2 Research. Index to All Books on the Physical Sciences in English, 1967 through January, 1974. Rockville, Md.: Marc 2 Research, 1974. 457p. \$27.00. (74-75515). (ISBN 0-914358-01-4).

Marshall, John David. Of, By, and For Librarians. Hamden, Conn.: Shoestring, 1974. 242p. \$8.00. (73-16428). (ISBN 0-208-01333-4).

Sugden, Virginia M. The Graduate Thesis. New York: Pitman, 1973. 157p. \$6.95. (73-82105).

Trzyna, Thaddeus C., ed. Directory of Consumer Protection and Environmental Agencies. Orange, N.J.: Academic Media, 1973. 627p. \$39.50. (72-75952). (ISBN 0-87876-032-6).

U.S. Department of Health, Education and Welfare. Records, Computers and the Rights of Citizens. Washington, D.C.: GPO, 1973. 344p. \$2.45. (73-13449). (ISBN 0-262-08070-2).

Waters, Marie B. Worldwide Directory of Computer Companies, 1973-74. Orange, N.J.: Academic Media, 1973. 633p. $\$ 39.50$. (77-114301). (ISBN 0-8787633-4). 
The following abstracts are based on those prepared by the ERIC Clearinghouse on Information Resources, Stanford Center for Research and Development in Teaching, School of Education, Stanford University, Stanford, CA 94305.

Documents with an ED number may be ordered in either microfiche (MF) or hard copy (HC) only from ERIC Document Reproduction Service, P.O. Drawer O, Bethesda, MD 20014. Orders must include ED number and specification of format desired. A $\$ 0.50$ handling charge will be added to all orders. Payment must accompany orders totaling less than $\$ 10.00$. Orders from states with sales tax laws must include payment of the appropriate tax or include tax exemption certificates.

Documents available from the National Technical Information Service, Springfield, VA 22151 have NTIS number and price following the citation.

Library Job Descriptions, Examples Covering Major Work Areas. Dale E. Shaffer. 1973. 44p. (ED 078 845, MF$\$ 0.65)$.

The writing of job descriptions is a universal management practice in every type of organization. Whatever the size or type of library, the need exists for written descriptions of every job performed. There are no standard job descriptions available because work duties differ among libraries. Tasks are grouped differently and jobs are given different titles. The organization of a small library, for example, is quite different from that of the large library having a high degree of specialization. Total work performed in operating different types of libraries is delegated in widely varying ways. This is a fact of librarianship and probably cannot be avoided. The job descriptions presented herein are offered as examples for library directors to use as guidelines in drafting statements to fit their own particular operations. In total, the descriptions attempt to cover most of the major work activities performed in libraries, whether they be in public, college, university, or special libraries. Although the statements were prepared for use in a small college library, they are equally adaptable to any type of library. It is highly recommended that a unique job description be written for every job in every library. Professional management requires the use of such tools in the proper allocation and division of work.

\section{Library Goals and Obectives: Literature}

Review. Norman J. Crum, ERIC Clearinghouse on Library and Information Science, Washington, D.C. 1973. 42p. (ED $082794, \mathrm{MF}-\$ 0.65, \mathrm{HC}-\$ 3.29)$.

The literature of library goals and objectives is reviewed, evaluated, and structured to serve those in university, public, and special libraries who are planning the future direction of their organizations. The emphasis is upon overall goals and objectives-not low-level, organizational nor state or other area-type goals. Background factors and trends, types and definitions, benefits and importance, broad surveys, guidelines and problems of formulation, further research recommendations, and a bibliography of 141 references, arranged by author, make up the review.

Faculty Loan Regulations in ARL Academic Libraries. University Libraries Technical Paper No. 4. Paul Gherman and others, Wayne State University, Detroit, Michigan. 1973. 9p. (ED 082 792, $\mathrm{MF}-\$ 0.65, \mathrm{HC}-\$ 3.29)$.

A survey of faculty loan regulations in force at Association of Research Libraries (ARL) academic libraries indicated that 
there is little equity, between faculty and students, of loan regulations; that it is not possible to determine loan policies from the regulations that support policy; and that many of the libraries appear to be unable to force compliance with faculty loan regulations.

Academic Library Statistics: 1963/64 to 1971/72. A Compilation of Statistics from the Seventy-Eight University $\mathrm{L} i$ brary Members of the Association of Research Libraries. Association of Research Libraries, Washington, D.C. 1972. 119p. (ED 082 791, MF-\$0.65, HC$\$ 6.58)$.

Statistical data is presented in tabular form for the member libraries of the Association of Research Libraries (ARL) under the following headings: volumes in library, volumes added (gross), volumes added (net), total microform units in library, current periodicals, professional staff full time equivalents, nonprofessional staff full time equivalents, total staff full time equivalents, student assistants full time equivalents, library materials, binding, total materials in binding, total salaries and wages, other operating expenditures, total library operating expenditures, Ph.D.'s awarded, and number of $\mathrm{Ph}$.D. fields.

\section{Advice on Making a College Orientation}

Video-Tape. Margaret Guss and others. 1973. 9p. (ED $082781, \mathrm{MF}-\$ 0.65$, HC $-\$ 3.29)$.

The purpose of this article is to assist librarians who are preparing a videotape orientation program suitable for large audiences, composed mainly of college freshmen. It results from the authors' experiences of planning and taping a television library orientation program and is directed toward the librarian who is required to prepare such a program but is inexperienced in videotaping. Stress is placed upon the practical, videotaping hints and common pitfalls to be avoided, rather than the technical aspects.

\section{Proposal for a University of Californial California State University and Colleges Inter-Segmental Machine-Readable Li-}

brary Patron Card. By Kenneth Weeks, California University, Berkeley, Institute of Library Research. 1973. 27p. (ED 082 $777, \mathrm{MF}-\$ 0.65, \mathrm{HC}-\$ 3.29)$.

It is proposed that the University of California and the California State University and Colleges systems cooperate in the development of a compatible machine-readable library patron card or badge that would meet the requirements of campuses in both systems. For discussion purposes, this report suggests the basic features to be included in such a card. As to physical characteristics, the card should be designed to be compatible with a wide variety of available badge reader/transactor equipment. As to contents, the card should include the following machine-readable elements: borrower I.D. number (Social Security number when available), borrower status code, and campus code. A campus coding scheme is suggested. Borrower name, borrower status code, university or college (including campus) name, and validation or expiration date should be humanreadable. Signing of the card should be accomplished as part of the card preparation process; inclusion of photograph could be left to local option. The back of the card should carry conditions governing its use, as well as campus administrative information.

Interlibrary Loan Borrowing: A Methodology for Analysis. By Michael A. Newsham. 1973. 120p. (ED $082771, \mathrm{MF}-$ $\$ 0.65, \mathrm{HC}-\$ 6.58)$.

The research reported in this paper examined data related to the characteristics of interlibrary loan borrowers, the material borrowed, the question of cost and time it takes to acquire the material, and staff information and procedures. The variables were coded onto computer cards and then tabulated into frequency tables by the computer. There were four major findings discovered as a result of this investigation. First, the average total time it takes for a request to be filled is twenty-three days. Borrowing costs were insignificant, while 75 percent of the photocopied requests cost only ten cents per page. The concept of a heavy user of interlibrary loan from one de- 
partment or agency was the third major finding. The fourth and final finding was the percentage breakdown of the number of requests filled on successive passes. This methodology could conceivably be applied to the interlibrary loan services of other medium and large research libraries.

\section{Library Automation: Guidelines to Cost-} ing. By Geoffrey Ford. Office for Scientific and Technical Information, London, England. 1973. 60p. (ED 082 757, MF$\$ 0.65)$.

As with all new programs, the costs associated with library automation must be carefully considered before implementation. This document suggests guidelines to be followed and areas to be considered in the costing of library procedures. An existing system model has been suggested as a standard (Appendix A) and a classification of library tasks originally devised for the British Library is put forward as a tentative basis for a standard (Appendix B). A check list of cost headings is given in Appendix G. Given a basis such as is provided by these, the costing of manual and automated procedures can proceed. Appendices C-F refer to particular data recording methods. The heads to be considered in costing proposed systems (in particular, automated systems) are covered in some detail, and it is recommended that decisions on implementation of new systems are made only after estimates of costs have been made for a well-defined planning period. An accurate knowledge of costs assists in the decisionmaking process. Costing is a straightforward exercise when carried out systematically; the difficult task is the allocation of resources. In the university field this includes a long look at the university as a whole, and this work is now beginning to be done. The appendices to this report are intended to give assistance in the analysis of costs and the preparation of budgets.

\section{A Study with Computer-Based Circulation Data of the Non-Use and Use of a Large Academic Library. Final Report. By John Lubans, Jr., and others. Colorado University, Boulder, Libraries. 1973. 85p.}

(ED $082756, \mathrm{MF}-\$ 0.65, \mathrm{HC}-\$ 3.29$ ).

Computer-based circulation systems, it is widely believed, can be utilized to provide data for library use studies. The study described in this report involves using such a data base to analyze aspects of library use and non-use and types of users. Another major objective of this research was the testing of machine-readable circulation data serving as the resource for a variety of computer-based studies. These studies were designed to supply information for decision making in libraries in such areas as collection development and book budget allocations. This document reports upon a study of the value of computer-based circulation data in administrative decision making in a large academic library. Computer programs were written to produce a variety of outputs including listings for survey purposes of non-users/users; books most frequently used; use of the library by department or major of the user; and, the use of books by their classification code by academic level of user. It is the conclusion of this study that such experimental by-products of a computer-based circulation system offer useful data for book selection, budgetary allocation, and the surveying of the library's clientele. A major question is raised as to what is library use/non-use. From the survey in this study it may be incorrect to categorize users or non-users as individuals who do or do not take out books for home use.

\section{Standards Recommended for Canadian} Community College Libraries. Canadian Association of College and University Libraries, Ottawa (Ontario). Canadian Community College Library Committee. 1973. 9p. (ED $081458, \mathrm{MF}-\$ 3.00$ ).

In November 1970, the Canadian Association of College and University Libraries appointed a committee to examine existing standards and to recommend to the association's membership, standards appropriate to Canadian community colleges. Under the heading of Qualitative Standards recommendations are made for administration and organization, the budget, building, collections, services, and staff. Quantitative Standards recommendations cover the budget, collections, seating, and staff. 